\title{
COVID-19's impact on neglected pharmaceutical staff: wake-up call for needed research
}

\author{
Richard Antony Powell ${ }^{1,2,3^{*}} \mathbb{0}$, Shivali Lakhani ${ }^{4}$, Marsha Alter ${ }^{4}$, Steven Guan ${ }^{2}$, Jehanita Jesuthasan ${ }^{5}$ and \\ Dasha Nicholls ${ }^{1,5}$
}

\begin{abstract}
Discussion of the necessity of the compulsory vaccination of UK patient-facing care workers as an employment conditionality has deflected from the initial and ongoing impact of Coronavirus disease on relatively neglected occupational groups themselves, including community pharmacists. This commentary highlights the relative lack of research investigating the mental health and wellbeing impact of the pandemic on this occupational group in England and urges further study of their needs and experiences to inform evidence-based supportive psychological interventions.
\end{abstract}

Keywords: COVID-19, Community pharmacy, Mental health, Pandemic, Pharmacists, Professional roles

\section{Main text}

Valid discussion of the necessity and aptness of the compulsory vaccination of UK patient-facing care workers as an employment conditionality [1-3] has deflected from the initial and ongoing impact of Coronavirus disease (COVID-19) on relatively neglected occupational groups themselves.

Evidence of the severity of detrimental effect of the virus, including morbidity and mortality, on secondary care service personnel is increasing $[4,5]$. Growing data exist on the short-term psychological sequelae of the pandemic in its first and second waves among acute, hospital-based doctors and nursing staff [6-9]. However, the impact of the pandemic on the mental health and wellbeing of secondary care support staff (e.g., administrators, cleaners) and community-based staff (e.g., primary care

\section{Editorial Responsibility: Zaheer Babar, University of Huddersfield, UK.}

*Correspondence: r.powell@imperial.ac.uk

${ }^{2}$ Department of Primary Care and Public Health, Faculty of Medicine,

School of Public Health, Imperial College London, Sir Alexander Fleming

Building, South Kensington Campus, London SW7 2AZ, England

Full list of author information is available at the end of the article physicians, social care staff), on which services rely, have been comparatively overlooked [10].

Community pharmacists comprise one such occupational group. Working as frontline healthcare workers, pharmacists have acted as the first point of patient contact, triaging patients, disseminating information, managing medication shortages, and experiencing patient harassment, with resultant increased workload and potential mental health consequences [11].

International research has been conducted exploring the impact of the pandemic on the pharmacy profession, as part of wider healthcare worker studies [12-14] and as a dedicated professional group $[11,15,16]$. One of the most ambitious studies covered over 500 pharmacists in 31 Commonwealth countries [17]. It found the majority reported being at least somewhat worried (90\%), and over $65 \%$ very or extremely worried, about COVID-19's impact personally and professionally, and nearly twothirds found it somewhat or very difficult to work effectively during the pandemic [17].

Despite being one of the four pillars of the country's primary care system-numbering over 11,500 pharmacies across England [18], and nearly 56,000 pharmacists original author(s) and the source, provide a link to the Creative Commons licence, and indicate if changes were made. The images or other third party material in this article are included in the article's Creative Commons licence, unless indicated otherwise in a credit line to the material. If material is not included in the article's Creative Commons licence and your intended use is not permitted by statutory regulation or exceeds the permitted use, you will need to obtain permission directly from the copyright holder. To view a copy of this licence, visit http://creativecommons.org/licenses/by/4.0/. The Creative Commons Public Domain Dedication waiver (http://creativeco mmons.org/publicdomain/zero/1.0/) applies to the data made available in this article, unless otherwise stated in a credit line to the data. 
and over 24,000 pharmacy technicians across the UK [19]-incomparable research has been conducted among English pharmacists. One of the few such studies was the nationwide "Workforce Mental Health and Wellbeing Survey" conducted by the Royal Pharmaceutical Society (RPS) with the Pharmacist Support charity during the pandemic's first wave [20]. The study results were startling: nearly a third (31\%) of pharmacists reported that COVID-19 had impacted their mental health significantly but that $44 \%$ felt uncomfortable accessing employer- and NHS-funded occupational health services, citing confidentiality and trust, stigma and judgement, and their potential to harm their careers. Among this group not seeking support, those working in the community were most reluctant (51\%), compared to those in general practice $(46 \%)$ and hospi$\operatorname{tal}(31 \%)$.

In relation to their work, $72 \%$ reported the pandemic had negatively affected their mental health and wellbeing, manifesting as increased service demand, inadequate staffing, long hours and a lack of breaks and time off. Unsurprisingly, the overwhelming majority (89\%) scored as being at high risk of burnout, one third (33\%) had considered leaving their job, and $34 \%$ had considered leaving the profession. However, the most disarming finding was comparing the study results with pre-pandemic 2019 data, when $74 \%$ reported negative mental health and wellbeing from their work environment, and $80 \%$ scored being at high risk of burnout [21].

The broadly consistent personal and occupational stress and burnout found among English pharmacists appears embedded in the profession's self-perception of being "little more than glorified retailers," their role within the healthcare sector often "downplayed and even underplayed" [22]. This stands in contrast to the general public's positive view of the profession ( $89 \%$ in one study) as "essential" during the pandemic, adapting well to the virus, offering a "good patient service" and going "above and beyond" [23]. It is also linked to the precarious financial health of many pharmacies-with three-quarters anticipated to be loss-making within four years-arising from the 2016 funding cuts they received and the current settlement of 5 years' flat funding [24].

Lastly, in the post-pandemic landscape facing the NHS, further demands are being placed on community pharmacists to assist with addressing the accumulated backlog of patient appointments and cases. Given their often-easy high street accessibility, pharmacies are well positioned to act as an early diagnostic and advisory entry point to the healthcare system, thereby relieving pressure on general practitioners (GPs). However, an audit recently revealed English pharmacies are already providing 1.1 million unremunerated consultations per week [25], while rising patient numbers and a shortage of GPs threaten to overwhelm the system [26].

\section{Conclusions}

The net result of these multi-factorial pressures, compounded by COVID-19, is a real need for further study of this under-researched group. There is a pressing need to look at the longer-term mental health and wellbeing needs of pharmacists in the post-pandemic environment and its new realities, ideally longitudinally. But it is also imperative to understand how these are interrelated with, and potentially exacerbated by, underlying historical and contemporary personal and professional challenges, be they contractual, financial, and/or occupational burden. It is only by appreciating these needs and experiences that supportive, evidence-based psychological interventions to meet them can be developed and recommended.

\section{Abbreviations}

COVID-19: Coronavirus disease; GP: General practitioner; NHS: National Health Service; RPS: Royal Pharmaceutical Society.

\section{Acknowledgements}

Not applicable.

\section{Authorship statement}

RAP and DN's independent contribution to this article is supported by the National Institute for Health Research Applied Research Collaboration Northwest London. The views expressed in this publication are those of the authors and not necessarily those of the National Institute for Health Research or the Department of Health and Social Care

\section{Authors' contributions}

RAP drafted the initial manuscript, to which all co-authors provided critical and substantive input. All authors read and approved the final manuscript.

\section{Funding}

The research presented in this manuscript is independent research funded by the National Institute for Health Research Northwest London Applied Research Collaboration (ARC) and by the Imperial College COVID-19 Research Fund (Grant Number P88408).

Availability of data and materials

Not applicable.

\section{Declarations}

Ethics approval and consent to participate

Not applicable.

Consent for publication

Not applicable.

\section{Competing interests}

The authors declare that they have no competing interests.

\section{Author details}

${ }^{1}$ NIHR ARC Northwest London, London, England. ${ }^{2}$ Department of Primary Care and Public Health, Faculty of Medicine, School of Public Health, Imperial College London, Sir Alexander Fleming Building, South Kensington Campus, London SW7 2AZ, England. 'Ethnicity and Health Unit, School of Public Health, Imperial College London, London, England. ${ }^{4}$ Middlesex Pharmaceutical Group, 
London, England. ${ }^{5}$ Department of Brain Sciences, Imperial College London, London, England.

Received: 22 October 2021 Accepted: 27 October 2021

Published online: 04 November 2021

\section{References}

1. Anon. Compulsory vaccinations for care home staff in England backed by MPs. BBC News; 2021. https://www.bbc.com/news/uk-57829135. Accessed 13 July 2021.

2. Hayes L, Pollock AM. Mandatory covid-19 vaccination for care home workers. BMJ. 2021;374: n1684. https://doi.org/10.1136/bmj.n1684pmid: 34233895.

3. Shemtob L, Ferris M, Asanati K, Majeed A. Vaccinating healthcare workers against covid-19. BMJ. 2021;374:n1975. https://doi.org/10.1136/bmj. n1975 (Published 11 August 2021).

4. Levene LS, Coles B, Davies MJ, Hanif W, Zaccardi F, Khunti K. COVID-19 cumulative mortality rates for frontline healthcare staff in England (Version 1). University of Leicester, 2020. https://hdl.handle.net/2381/12593 696.v1.

5. van der Plaat DA, Madan I, Coggon D, van Tongeren M, Edge R, Muiry R, et al. Risks of COVID-19 by occupation in NHS workers in England. Occup Environ Med. 2021. https://doi.org/10.1136/oemed-2021-107628.

6. Greenberg N, Weston D, Hall C, Caulfield T, Williamson V, Fong K. Mental health of staff working in intensive care during COVID-19. Occup Med. 2021:71:62-7.

7. Lamb D, Gnanapragasam S, Greenberg N, Bhundia R, Carr E, Hotopf M, et al. Psychosocial impact of the COVID-19 pandemic on 4378 UK healthcare workers and ancillary staff: initial baseline data from a cohort study collected during the first wave of the pandemic. Occup Environ Med. 2021. oemed-2020-107276. doi: https://doi.org/10.1136/oemed-2020107276. Online ahead of print

8. Liberati E, Richards N, Willars J, Scott D, Boydell N, Parker J, et al. A qualitative study of experiences of NHS mental healthcare workers during the Covid-19 pandemic. BMC Psychiatry. 2021:21:250

9. Pappa S, Barnett J, Berges I, Sakkas N. Tired, worried and burned out, but still resilient: a cross-sectional study of mental health workers in the UK during the COVID-19 pandemic. Int J Environ Res Public Health. 2021;18:4457.

10. Franklin P, Gkiouleka A. A scoping review of psychosocial risks to health workers during the Covid-19 pandemic. Int J Environ Res Public Health. 2021;18:2453.

11. Elbeddini A, Wen CX, Tayefehchamani Y, To A. Mental health issues impacting pharmacists during COVID-19. J Pharm Policy Pract. 2020;13:46.

12. AlAteeq DA, Aljhani S, Althiyabi I, Majzoub S. Mental health among healthcare providers during coronavirus disease (COVID-19) outbreak in Saudi Arabia. J Infect Public Health. 2020;13:1432-7.

13. Ardebili ME, Naserbakht M, Bernstein C, Alazmani-Noodeh F, Hakimi H, Ranjbar H. Healthcare providers experience of working during the COVID19 pandemic: a qualitative study. Am J Infect Control. 2021;49:547-54.
14. Osório FL, Silveira ILM, Pereira-Lima K, de Souza Crippa JA, Hallak JEC, Zuardi AW, et al. Risk and protective factors for the mental health of Brazilian healthcare workers in the frontline of COVID-19 pandemic. Front Psych. 2021;12:1299.

15. Lange $M$, Joo S, Couette P-A, de Jaegher S, Joly F, Humbert X. Impact on mental health of the COVID-19 outbreak among community pharmacists during the sanitary lockdown period. Ann Pharm Fr. 2020;78:459-63.

16. Hayden JC, Parkin R. The challenges of COVID-19 for community pharmacists and opportunities for the future. Irish J Psychol Med. 2020;37:198-203.

17. Ashiru-Oredope D, Chan AHY, Olaoye O, Rutter V, Babar Z, The C. P. A. COVID-19 Action Team. Needs assessment and impact of COVID-19 on pharmacy professionals in 31 commonwealth countries. J Pharm Policy Pract. 2020;13:72.

18. Baird B, Beech J. Community pharmacy explained. The King's Fund 16 December; 2020. https://www.kingsfund.org.uk/publications/commu nity-pharmacy-explained. Accessed 14 Oct 2021.

19. General Pharmaceutical Council. Annual report: annual fitness to practise report and annual accounts. London: General Pharmaceutical Council; 2021.

20. Royal Pharmaceutical Society. Workforce wellbeing report, November 2020. London: Royal Pharmaceutical Society; 2020.

21. Royal Pharmaceutical Society. Pharmacists suffer the mental health consequences of workplace pressures; 2019. Royal Pharmaceutical Society. https://www.rpharms.com/about-us/news/details/Pharmacists-sufferthe-mental-health-consequences-of-workplace-pressures. Accessed: 14 Oct 2021.

22. Shaw I. Jackie Doyle-Price: 'The health establishment treats pharmacists as little more than glorified retailers.'The Pharmacist July 2021. https:// www.thepharmacist.co.uk/news/jackie-doyle-price-the-health-estab lishment-treats-pharmacists-as-little-more-than-glorified-retailers/. Accessed 14 Oct 2021.

23. National Pharmacy Association. Public see pharmacies as key to the future of healthcare in wake of pandemic; 2020. National Pharmacy Association. https://www.npa.co.uk/news-and-events/news-item/publicsee-pharmacies-as-key-to-the-future-of-healthcare-in-wake-of-pande mic/. Accessed 13 Oct 2021

24. Anon. Most pharmacies to be loss-making within four years. Pharmacy Magazine; 2020. https://www.pharmacymagazine.co.uk/analysis/mostpharmacies-to-be-loss-making-within-four-years. Accessed 28 Sept 2021.

25. Pharmaceutical Services Negotiating Committee. Pharmacies in England carry out 58 million consultations a year; 2021. Pharmaceutical Services Negotiating Committee. https://psnc.org.uk/our-news/pharmacies-inengland-carry-out-58-million-consultations-a-year/. Accessed 28 Sept 2021.

26. Triggle N. How rising patient numbers threaten to overwhelm GPs. BBC News; 2021. https://www.bbc.com/news/health-57229848. Accessed 12 Oct 2021.

\section{Publisher's Note}

Springer Nature remains neutral with regard to jurisdictional claims in published maps and institutional affiliations.

Ready to submit your research? Choose BMC and benefit from

- fast, convenient online submission

- thorough peer review by experienced researchers in your field

- rapid publication on acceptance

- support for research data, including large and complex data types

- gold Open Access which fosters wider collaboration and increased citations

- maximum visibility for your research: over 100M website views per year

At BMC, research is always in progress.

Learn more biomedcentral.com/submissions 